\title{
PROSES FONOLOGIS GENERATIF BAHASA PROKEM REMAJA DI INDONESIA
}

\author{
Riski Ramadhanti Anasti ${ }^{1}$, Silvia Ridanta ${ }^{2}$, Syahrul Ramadhan ${ }^{3}$ \\ Fakultas Bahasa dan Seni, Universitas Negeri Padang \\ ${ }^{1}$ ramadhanti940@gmail.com, ${ }^{2}$ silviaridanta460@gmail.com
}

\begin{abstract}
Abstrak
Penelitian ini bertujuan untuk mengkaji proses fonologis bahasa prokem yang digunakan remaja di Indonesia. Penelitian ini menggunakan metode deskriptif kualitatif dan menggunakan pendekatan fonologi generatif. Data penelitian ini adalah data fonologis dari bahasa prokem remaja. Data penelitian ini diambil dengan metode refleksif introspektif untuk bahasa yang dikuasai oleh penulis. Selain itu, data juga diambil dari buku-buku sumber yang membahas mengenai bahasan pada penelitian ini. Cara yang digunakan dalam menganalisis data adalah mengumpulkan data,menganalisis data, membuat kajian fonologis, dan memuat hasil temuan. Hasil dari penelitian ini ditemukan bahwa bahasa prokem memiliki ciri-ciri menggunakam vokal /e/ dan /o/, melesapkan bunyi,dan adanya pengenduran bunyi serta penguatan vokal. Dari hasil penelitian ini juga ditemukan kecenderungan bahasa prokem dalam menyingkat bentuk dan memodifikasi bentuk.
\end{abstract}

Kata Kunci: bahasa prokem (gaul) remaja, fonologi generatif.

\begin{abstract}
This study aims to examine the phonological process of the language used by teenagers in Indonesian. This study uses a qualitative descriptive method and uses a generative phonological approach. The data of this study are phonological data from adolescent language. The data of this study were taken by an introspective reflexive method for languages mastered by the author. In addition, data is also taken from siurce books that discuss the discussion in study. The method used in analyzing data, making phonological studies, and loading findings. The results of this study found that slang has the characteristics of using vocal $E$ and $O$, blasting sound and the presence of sound relaxation an vocal strengthening. The results of this study also found the tendency of language to abbreviate forms and modify.
\end{abstract}

Keywords: slang, generative phonology

\section{PENDAHULUAN}

Bahasa merupakan sistem lambang bunyi. Bahasa digunakan dalam kehidupan seharihari sebagai alat komunikasi dengan maksud menyampaikan suatu pesan (Chaer, 2007: 5). Berdasarkan pengertian bahasa yang menyebutkan bahwa bahasa merupakan sistem lambang bunyi dan ilmu yang mempelajari bunyi bahasa disebut dengan fonologi. Oleh beberapa pakar, fonologi dimaksudkan sebagai ilmu linguistik yang mempelajari, menganalisis dan membicarakan runtutan bunyi-bunyi bahasa itu.

Selain itu, beberapa ahli mengatakan bahwa fonologi adalah salah satu cabang ilmu bahasa umum (linguistik) yang mempelajari bunyi-bunyi bahasa baik bahasa 
masyarakat yang sudah maju maupun masyarakat yang masih primitif dalam segala bentuk dan aspeknya (Amril dan Ermanto, 2007:8).

Fonologi generatif adalah aliran yang pada awalnya dipandang sebagai subordinat dari teori yang dilahirkan oleh Chomsky dan para pengikutnya pada tahun 1968. Fonologi generatif ini pada umumnya membicarakan mengenai proses fonologis suatu bahasa. Oleh karena itu, sering ditemukan kaidah-kaidah perubahan bunyi.

Setiap bahasa yang digunakan di dalam suatu kelompok masyarakat dapat diengaruhi oleh faktor sosial, pendidikan, usia,letak geografi dan lingkungannya. Jadi, keberadaan seseorang dalam kelompok yang menggunakan bahasa tertentu akan mempengaruhi bahasanya. Hal itu juga yang meyebabkan adanya dialek sosial dan dialek geografi.

Dalam penelitian ini akan dibahas mengenai proses fonologis pada bahasa prokem remaja di Indonesia. Dari data yang disajikan penulis mencoba memaparkan analisis perubahan bunyi pada bahasa yang digunakan remaja di Indonesia. Bahasa yang digunakan oeh remaja tersebut memiliki maksud dan tujuan tertentu.

Bahasa prokem atau yang biasa disebut bahasa gaul ini sebenarnya sudah da sejak dekade 1990-an di media elektronik seperti radio dan televisi. Kata-kata yang digunakan sepintas sama namun konteks dan maknanya tidak pada tempatnya. Meluasnya penggunaan bahasa ini berawal dari bahasa yang digunakan oleh kelompok waria dan gay (homoseksual). Bahasa yang digunakan oleh kelompo waria tersebut dinamakan dengan bahasa binan, kemudian dinamakan bahasa gaul .

Kepopuleran bahasa gaul ini sangat didukung dengan keadaan remaja di Indonesia yang mudah dipengaruhi oleh lingkungan sekitarnya. Jadi, ketika ada satu bahasa yang dianggap menarik, mereka akan lebih cepat menyerapnya dan digunakan sebagai alat komunikasinya. Bahasa prokem ini adalah bahasa yang bebas dipermainkan demi tujuan dan identitas kelompok (Bambang, 2009 :7).

Bahasa prokem termasuk salah satu jenis every talk, juga dapat digolongkan dalam casual language karena memenuhi beberapa kriteria seperti ujaran-ujaran yang spontan (spontaneity pheomena), everyday vocabulary and colloquial expressions. Bahasa ini selain memiliki ciri-ciri fonologis yang khusus, juga diwarnai oleh munculnya slang. Slang-slang remaja sangat khas sesuai dengan usia mereka dan menandai keanggotaan dari sebuah komunitas yang khusus yaitu anak muda (Sartini, 2012:212).

Berdasarkan uraian di atas, tujuan penulisan ini adalah untuk mendapatan gambaran proses-proses dan kaidah-kaidah fonologis bahasa prokem remaja dengan pendekatan fonologi generatif yaitu analisis fonologi yang lengkap, sederhana, dan hemat. Tinjauan fonologi generatif berkaitan dengan tujuan di atas, hasil yang diharapkan adalah dalam bahasa prokem remaja terdapat fonologi generatif yang berkecenderungan dalam bahasa prokem tersebut. Teori yang digunakan dalam tulisan ini adalah Teori Fonologi Generatif merupakan teori bahasa yang dikenal sebagai Tata Bahasa Generatif. Tata bahasa ini merupakan sruktur bahasa dari lahir sehingga menghasilkan fonologi yang fonetik.

Konsep dasar fonologi generatif adalah setiap morfem memiliki bentuk dasar, di dalam bentuk dasar itu memiliki lebih dri satu bentuk fonetik. Semua varian morfem ini yang terjadi dalamm lingkungan sehari-hari. Suatu bentuk fonetik ini harus bervariasi yang sederhana pada tata bahasa yang dibicarakan. Begitu juga dalam bahasa prokem remaja, bentuk fonetik bahasa tersebut memiliki variasi yang banyak (Masnur, $2008: 10$ ). 


\section{METODE PENELITIAN}

Dalam tulisan ini rancangan yang digunakan adalah deskriptif kualitatif. Penelitian deskriptif merupakan adalah penelitian untuk mengumpulkan informasi mengenai status suatu gejala. Tujuannya adalah membuat penjelasan secara sistematis, faktual dan akurat mengenai sifat populasi di daerah tertentu. Pendekatan yang digunakan adalah fonologi generatif. Fonologi generatif merupakan perubahan bunyi dari rongga mulut manusia yang menghasilkan fonem atau suara, maka fonologis ini sangat dibutuhkan oleh manusia untuk berbahasa sehari-hari. Data penelitian ini diambil dengan metode refleksif introspektif untuk bahasa yang dikuasai oleh penulis. Selain itu, data juga diambil dari buku-buku sumber yang membahas mengenai bahasan pada penelitian ini. Cara yang digunakan dalam menganalisis data adalah mengumpulkan data,menganalisis data, membuat kajian fonologis, dan memuat hasil temuan.

\section{HASIL DAN PEMBAHASAN \\ Fonologi Generatif}

Teori generatif ini mempunyai tataran tata bahasa. Pada teori ini, mengenai perkembangan generatif dapat diaplikasikan dengan tataran fonologis generatif. Yusuf (1998: 92), menjelaskan bahwa fonologi generatif ini pertama kali muncul di Amerika dan Morris Halle adalah orang pertama yang menerapkan teori ini. Kesimpulannya, fonologi generatif ini berhubungan dengan suara (bunyi) dan makna, representatif fonetik suatu bahasa.

Dari uraian di atas, fonologi generatif ini berasal dari komponen tataran tata bahasa yang diterapkan pada bidang fonologi. Proses fonologi suatu perubahan bunyi dan makna berbuah menjadi fonologi generatif. Kesimpulannya, fonologi generatif merupakan perubahan bunyi dari rongga mulut manusia yang menghasilkan fonem atau suara, maka fonologis ini sangat dibutuhkan oleh manusia untuk berbahasa sehari-hari.

\section{Bahasa Prokem}

Bahasa prokem merupakan bahasa khas anak muda. Bahasa prokem artinya sama dengan bahasa slang. Bahasa prokem terdapat dikalangan anak muda/remaja. Bahasa prokem/gaul merupakan bahasa yang bebas dipermainkan oleh anak remaja demi tujuan tertentu. Ragam ini masuk ke dalam kehidupan para remaja zaman sekarang sehingga memunculkan istilah-istilah gaul dalam kehidupannya. Ragam bahasa prokem ini ialah digunakan oleh siapa saja yang mempergunakan bahasa ini. Dalam bahasa prokem ini, bukan hanya anak remaja yang menggunakan, tapi orang dewasa juga menggunakan bahasa ini. Oleh karena itu, bahasa prokem sudah tersebar ke kalangan orang dewasa. Contoh bahasa prokem tersebut, yaitu bokap, nyokap, jomblo, bo'ong, gombal, gokil, keren, dll.

Bahasa prokem ini di samping memiliki ciri-ciri fonologis, juga diwarnai dengan bahasa slang. Slang merefleksikan usia penuturnya. Slang-slang remaja sangat khas menandai dirinya dalam komunitas anak muda sekarang. Di Indonesia anak muda sekarang mengucapkan kata sapaan menggunakan bahasa gaul, sedangkan orang zaman dulu, menggunakan bahasa sopan.

Ciri khas yang sangat menarik dari bahasa prokem ini adalah kaya dengan bunyibunyi bahasa dengan kaidah fonologisnya yang beragam, dan menarik bila dianalisis dari fonologi generatif.

Kata-kata dalam bahasa prokem bisa jadi berasal dari bahasa daerah yang diplesetkan dan diganti dari redaksi aslinya hingga terdengar lucu dan menarik. Bahasa 
yang awalnya berasal dari sekelompok orang di kalangan tertentu yang menciptakan bahasa ini seperti anak jalanan, waria,dan preman ini pada awalnya bertujuan agar orang lain tidak mengerti dengan apa yang sedang dibicarakakan. Namun, seiring berkembangnya zaman, bahasa ini menjadi bahasa keseharian yang digunakan oleh remaja dalam pergaulan sehari-hari.

\section{Ciri-ciri Fonologis Bahasa Prokem Remaja}

Dalam pengamatan yang sesuai dengan data dikumpulkan bahwa ada beberapa ciri-ciri fonologis dalam bahasa prokem remaja sebagai berikut.

\section{Cenderung menggunakan vokal /e/ dan /o/}

Bahasa prokem secara umum memiliki ciri pemunculan vocal /e/ sebagai vokal depan, tegang, dan tidak bulat. Sedangkan vokal /o/ sebagai vokal belakang, tengah, dan bulat. Munculnya variasi bunyi-bunyi itu ditandai dengan bunyi vokal (gue, loe, dan ogah) semua remaja menggunakan bunyi vokal tersebut.

\section{Melesapkan Bunyi}

Pelesapan bunyi bahasa prokem remaja ini memiliki kecenderungan pelesapan segmen seperti berikut. Pelepasan /s/ yang menjadi kata-kata dilesapkan didahului bunyi vokal.

$\begin{array}{ll}\text { /saja/ } & \text { (aja) } \\ \text { /sudah/ } & \text { (udah) }\end{array}$

Pelepasan ini adalah kaidah-kaidah kecil dari notasi ciri (kaidah pelepasan /s/). Kaidah fonologisnya sebaga berikut.

\section{Mengalami Pergenduran, Penguatan, dan Perpaduan Vokal}

\section{Pergenduran Vokal}

Perubahan vokal ini termask dalam pergenduran vokal atau pelemahan vokal. Berikut adalah kata-kata yang termasuk pergenduran vokal sebagai berikut.
a) /sangat/
(-banget)
b) /lapar/
(laper)
c) /ingat/
(inget)
d) /sempat/
(sempet)
e) /tetap/
(tetep)
f) /bosan/
(bosen)
g) /hangat/
(anget)

Data di atas menunjukkan bahwa vokal /a/.

\section{Penguatan Vokal}

Kata /mahal/ menjadi (mehong) mengalami penguatan atau keteganganvokal karena bunyi (e) dan (o) sama-sama tegang pengucapa vokalnya.

Ada fenomena lain dalam bahasa prokem remaja ini. Prosesnya dapat dilihat dari beberapa segi yaitu memodifikasikan bunyi itu menjadi /ong/ pada akhir kata dan terjadi penguatan vokal menjadi vokal /o/. proses tersebut dapat dilihat pada data berikut ini:
1) Laki-laki
2) Banci
$\longrightarrow$ lekong
3) Janda
$\longrightarrow$ bencong
4) Begini

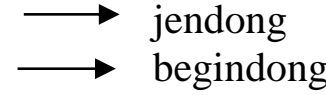




\section{Proses Perpaduan Vokal}

Proses ini hampir sama dengan proses persandian berpadunya bunyi, karena vokal menjadi bunyi vokal yang baru. Dalam bahasa prokem remaja ada beberapa kata yang mengandung perpaduan vokal. Contoh data sebagai berikut.

$\begin{array}{ll}\text { /balik/ } & \text { (balek) } \\ \text { /baik/ } & \text { (baek) } \\ \text { /ramai/ } & \text { (rame) } \\ \text { /santai/ } & \text { (sante) } \\ \text { /sampai/ } & \text { (sampe) }\end{array}$

Bunyi (ai) dalam bahasa Indonesia berubah menjadi bunyi (e) dalam bahasa prokem remaja. Vokal ini secara fonetis direalisasikan sebagai vokal depan, tengah, dan belakang, tetapi tidak bulat.

\section{Kecenderungan Umum Bahasa Pergaulan Remaja}

\section{Cenderung Menyingkat Bentuk}

Pengguna bahasa prokem cenderung dalam menyingkat bentuk-bentuk yang digunakan dalam berkomunikasi. Kata-kata tersebut antara lain: ape, bete, cape, rame, lemot, dan sebagainya.

\section{Kecenderungan Memodifikasi Bentuk}

Sebagian besar bentuk bahasa prokem yang digunakan oleh remaja rata-rata sudah dimodifikasi menjadi bentuk yang baru dengan tujuan mempersingkat penyebutannya. Seperti halnya kata ayah dan ibu yang dimodifikasi menjadi nyokap dan bokap. Kata itu merupakan prokem remaja namun sudah meluas pemakaiannya.

Secara umum, kata-kata modifikasi bahasa remaja ini terdiri atas dua silaba untuk kelancaran dan kemudahan pengucapan. Kata seperti ini memiliki kemudahan dalam pengucapannya dengan tidak meninggalkan kaidah-kaidah aslinya. Menurut Kenstowics dan Kosseberth (dalam Sartini:2012), semua ungkapan dan morfemmorfem yang membentuknya memiliki satu bentuk asal dan satu gambaran fonetik.

Menurut Oetomo (dalam Sartini :2012), bentuk kata-kata seperti yang telah disebutkan di atas, disebut dengan bahasa binan. Kata-kata itu dibentuk dengan dua proses yakni (1) proses perubahan bunyi dalam kata yang berasal dari bahasa dari bahasa daerah atau bahasa Indonesia dan (2) proses penciptaan kata atau istilah baru atau pun penggeseran makna kata atau istilah (plesetan) yang sudah ada dalam bahasa daerah atau bahasa Indonesia

\section{SIMPULAN}

Dari hasil penelitian ini dapat disimpulkan. Pertama,fonologi generatif adalah bunyi dari rongga mulut manusia yang menghasilkan fonem atau suara, maka fonologis ini sangat dibutuhkan oleh manusia untuk berbahasa sehari-hari. Kedua, bahasa prokem adalah bahasa khas anak muda yang biasa digunakan dalam pergaulan sehari-hari. Ketiga, ciriciri fonologis bahasa prokemantara lain: cenderung menggunakan vokal /e/ dan /o/, melesapkan bunyi, dan mengalami pengenduran dan penguatan vokal. Keempat, memiliki kecenderungan menyingkat bentuk dan memodifikasi bentuk. 


\section{DAFTAR PUSTAKA}

Amril \& Ermanto. (2007). Fonologi bahasa Indonesia. Padang: UNP Press.

Chaer, A. (2007). Linguistik umum. Jakarta: Rineka Cipta.

Muslich, M. (2008). Fonologi bahasa Inonesia. Jakarta: PT Bumi Aksara.

Sartini, N. W. (2012). Bahasa pergaulan remaja analisis fonologis generatif. Jurnal Ilmu Humaniora, 12(2) http://journal.unair.ac.id/filterPDF/(3)B

Yulianto, B. (2009). Perkembangan fonologis bahasa anak. Surabaya: Unesa University Press.

Yusuf, S. (1998). Fonetik dan fonologi. Jakarta: PT Gramedia Pustaka Umum. 